\title{
Menyuarakan Hak tanpa Sekat: Sebuah Ekspresi Gerakan Sosial Petani
}

\author{
Ahmad Izudin ${ }^{1 *}$ \\ ${ }^{1}$ Program Studi Pengembangan Masyarakat Islam, Fakultas Dakwah dan Komunikasi, \\ Universitas Islam Negeri Sunan Kalijaga Yogyakarta - Indonesia
}

\begin{abstract}
This paper highlighted the social change of peasant in the process of facing any struggling movement. Applying a qualitative method and case study approach, the data in this research were collected by observation, interview, and document study. The data were analyzed using the theory of "Social-Economic Morality". By analyzing the data using this theory this article revealed the changing society in terms of peasant political attitude. This research found three important aspects. Firstly, compromise is a kind of strategy applied by peasants in their movement. Because there are no supporting factors for peasants to avoid the state's hegemony and exploitation, so the only strategy to deal with the expansive tendency of capitalism is by changing the political attitude of peasants. Secondly, the organizational consolidation is claiming peasant's rights. Thirdly, capacity development through the empowerment process is a form of compromise way of peasants' movement. These three compromise models are the ways to avoid conflict to escalate.

Tulisan ini menyoroti perubahan sosial petani dalam proses gerakan perlawanan. Dengan menggunakan metode penelitian kualitatif dan pendekatan studi kasus, data dalam penelitian ini dikumpulkan dengan observasi, wawancara, dan studi dokumen. Data dianalisis menggunakan teori "Moralitas Sosial-Ekonomi". Dengan menganalisis data menggunakan teori ini, artikel ini mengungkapkan perubahan sosial dalam hal sikap politik petani. Penelitian ini menemukan tiga aspek penting. Pertama, kompromi adalah semacam strategi yang diterapkan oleh petani dalam gerakan mereka. Karena tidak ada alasan bagi petani untuk menghindari hegemoni dan eksploitasi negara, maka satu-satunya strategi untuk menghadapi kecenderungan kapitalisme yang meluas adalah dengan mengubah sikap politik petani. Kedua, konsolidasi organisasi menuntut hak-hak petani. Ketiga, pengembangan kapasitas melalui pemberdayaan adalah bentuk cara kompromi gerakan petani. Tiga model kompromi ini adalah cara untuk menghindari konflik yang berkepanjangan.
\end{abstract}

Keywords: protest; social movement; peasant; Yogyakarta

*Korespondensi Penulis: Ahmad Izudin (ahmad.izudin@uin-suka.ac.id), Fakultas Dakwah dan Komunikasi, Universitas Islam Negeri Sunan Kalijaga, Jl. Laksda Adisucipto, Depok, Sleman, Daerah Istimewa Yogyakarta 55281. 


\section{Pendahuluan}

Petani Indonesia masih belum menunjukan tanda-tanda untuk terlepas dari jeratan kemiskinan. Meskipun dampak globlasisasi membawa pengaruh terhadap perubahan sistem pertanian dari tradisional menuju modern. Salah satu hal yang paling nampak adalah perubahan alat produksi dari tangan terampil manusia menjadi serba mesin, tidak terkecuali dalam praktik pertanian. Kondisi semacam ini tidak berpengaruh terhadap negara maju yang sudah terbiasa dengan penggunaan mesin sebagai alat produksi pertanian. Namun petani Indonesia tampak belum siap menghadapi perubahan tersebut (Izudin 2017; Susetiawan 2011)

Perubahan produksi pertanian menggunakan mesin, di satu sisi, berdampak positif bagi sebagian kelompok petani. Akan tetapi di sisi lain, perubahan ini justru membuat petani Indonesia kehilangan lahan garapan untuk penghidupan. Hal ini berpengaruh kepada diferensiasi dan diversifikasi pertanian. Untuk itu, pertama menurut hasil penelitian Husain, dinamika perubahan kelompok petani pedesaan cenderung kurang relevan jika tidak ditopang oleh instrumen pengembangan sumber daya yang berkualitas (Husain et al. 2018). Penggunaan teknologi pertanian juga berimplikasi kepada pengangguran terselubung. Alhasil, petani pedesaan yang tidak memiliki lahan pribadi, menganggur cukup lama yang menyebabkan pendapatan rumah tangga mengalami penurunan.

Kedua, sebagai analisis riset Adriani mengingatkan kita bahwa rasionalitas petani untuk memenuhi kebutuhan rumah tangga harus melakukan diversifikasi struktur pekerjaan. Tidak banyak yang dilakukan petani pedesaan, kecuali memaksimalkan potensi keluarga dengan mengambil pekerjaan di luar aktivitas pertanian (Adriani 2015). Ketiga, penelitian Rahmawati juga menyodorkan satu instrument penting tentang lapangan pekerjaan tidak cukup tersedia bagi masyarakat terutama petani. Pemerintah sebagai pemegang kebijakan lebih mengutamakan kepentingan para pemodal untuk melakukan ekspansi lahan garapan daripada memperkuat kualitas sumber daya manusia (Rahmawati 2003). Apabila industrialisasi sektor pertanian berlanjut tanpa memperhatikan subsistensi, bukan tidak mustahil, petani memilih pekerjaan di luar sektor pertanian. Namun, persoalan penting yang perlu diperhatikan adalah ketika pekerjaan yang dipilih bersifat unskill. Maka, petani yang mengalami diversifikasi lebih layak disebut dengan buruh serabutan.

Kondisi semacam ini, di era keterbukaan, akan memancing konfrontasi secara besar-besaran untuk menyuarakan nasib petani. Apalagi menyangkut nasib dan subsistensi pertanian. Subsistensi menjadi penting diperhatikan oleh para petani. Untuk itu, membangun kekuatan untuk menghindari kepentingan pemodal yang berkaitan erat dengan proses penyusunan kebijakan, menuntut para petani bergerak untuk berserikat. Salah satu bentuk gerakan yang harus dilakukan adalah pendirian organisasi. Membangun basis organisasi dapat menjadi sarana petani untuk melawan korporasi. Untuk itu, organisasi dengan bentuk serikat adalah jawaban untuk menunjukkan ekspresi kekecewaan kepada negara. Sejarah mencatat petani menunjukan taji melalui gerakan perlawanan untuk menentang ketidakadilan dan kesenjangan. Namun kegiatan ini dianggap se- 
bagai penghambat pembangunan bagi pemerintah, maka ada banyak konfrontasi dilakukan kepada petani (Sudibyo 1999). Konflik pun tidak dapat dihindari. Inilah realitas perjuangan petani di negeri ini.

Realitas ketidakadilan kepada petani membuka kesadaran para aktivis. Advokasi sosial pun dilakukan. Serikat Petani Indonesia (SPI) adalah lembaga organisasi sosial petani yang berupaya melakukan berbagai advokasi, terutama advokasi sosial yang dilakukan di Yogyakarta. Tentu ada banyak cerita klise yang cukup mencengangkan. Namun tidak semua kisah tersebut dapat diungkapkan dalam artikel ini. Untuk itu, melalui tulisan ini, peneliti mencoba untuk mengurai masalah gerakan sosial petani di Yogyakarta. Untuk itu, artikel ini menjawab tentang apakah gerakan sosial petani sudah berubah sehingga narasi perubahan perlawanan yang cenderung menghindari konflik sosial? Sebagaimana diketahui, gerakan perlawanan petani di Yogyakarta tidak se-ekstrim seperti daerah lain yang cenderung konfrontatif. Namun sebagai eksistensi organisasi, SPI berupaya menyuarakan hak-hak petani untuk terus bergerak akan tetapi tidak melakukan konfrontasi. Lebih tepatnya bergosiasi dengan berbagai pihak dan pemangku kebijakan. Secara teoritis, sikap gerakan sosial petani model tersebut, cenderung mendekati teori moral ekonomi yang ditawarkan oleh James Scott.

Dengan perubahan model gerakan sosial petani tersebut, maka artikel ini ditulis mengacu kepada refleksi fakta di lapangan melalui proses penelitian. Peneliti mencoba mengurai masalah dengan menggunakan metode kualitatif (Moleong
2010). Dipilihnya metode ini untuk mempermudah interpretasi data yang disampaikan oleh semua narasumber penelitian. Narasumber dipilih berdasarkan peran mereka dalam mengadvokasi persoalan petani di Yogyakarta. Setelah data terkumpul, peneliti mencoba untuk mendaring draft hasil wawancara dengan menggunakan metode reduksi data, display data, dan penarikan kesimpulan (Miles dan Huberman 1994). Setelah itu, peneliti melakukan interpretasi data sehingga menghasilkan cerita yang bersifat deskriptifkualitatif.

\section{Scottianisme: Model Gerakan Sosial Baru}

Mendengar kata 'petani' kita langsung terpikir, "mereka yang hidup dan menetap di desa" (Rahmat dan Izudin 2018). Justifikasi ini dapat dibenarkan, walaupun satu sisi tidak tepat juga. Sebab, pelabelan tersebut, seolah-oleh menjustifikasi bahwa orang-orang desa memiliki pola pikir primitif dan tidak mengenal dunia luar. Oleh sebab itu, stratifikasi sosial dalam sosiologi pedesaan menempatkan petani menjadi klasifikasi kelas sosial baru. Hidupnya tergantung pada tanah yang mereka tinggali (Rahmawati 2003).

Persepsi ini membuat para pemegang kebijakan, cenderung menempatkan petani sebagai kelompok sosial kelas kedua-kelas sosial yang tidak memiliki kemampuan untuk mandiri secara personal (Suharko 2006). Anggapan pemangku kebijakan tersebut memuluskan program pertanian yang menggunakan mesin-mesin industri sebagai upaya percepatan proses pembangunan namun kurang memperhatikan subsistensi hidup petani. Hal ini menyebabkan arah pembangunan 
pertanian cenderung berorientasi kepada kekuatan ekonomi yang hanya berpikir untung dan rugi.

Para pemegang kebijakan terkesan menempatkan kaum tani sebagai 'orang lemah' sehingga arah pembangunan cenderung bersifat top down dan tidak melibatkan partisipasi petani untuk memperbaiki nasib mereka secara mandiri. Berbagai macam cara pun ditempuhnya. Salah satu yang tampak adalah pendekatan legalformal. Dengan anggapan bahwa tanah yang ditempati petani untuk bercocok tanam adalah milik negara. Pendekatan ini-lambat launmembuat petani terusir dari tanah leluhurnya (Sulistyaningsih 2013).

Bagi para petani tidak ada pilihan lain kecuali diam. Sebagian berusaha melawan, dan sebagian besar lainnya memilih mengadu nasib di kota. Akhirnya, mereka mengisi bursa kerja murahan dari industri manufaktur atau terdampar ke sektor informal di kota-kota besar yang sewaktuwaktu bisa tergusur (Adriani 2015). Fakta ini menegaskan bahwa kaum tani adalah kelas tertindas.

Perlawanan petani memiliki sejarah panjang. Misalnya, catatan James C. Scott, perlawanan kaum tani hanya bersifat individu dan tidak terkoordinir atau disebut dengan kepasrahan kaum tani'. Mereka melakukan perlawanan hanya bersifat destruktif (pelampiasan kemarahan). Kelompok ini relatif tanpa kekuatan; menghambat, berpura-pura, pura-pura menurut, mencopet, pura-pura tidak tahu, memfitnah, pembakaran, sabotase, dan sebagainya (Scott 1985). Model perlawanan ini bercorak tradisional dan tanpa organisasi. Sebagaimana yang dibuktikan
Scott bahwa agak sulit mengkoordinir kaum tani untuk melakukan perlawanan atas kesewenangwenangan dari peranan otoritas pemegang kebijakan karena petani memiliki prinsip 'safety risk atau hanya terpaku kepada resiko kelaparan. Sebagaimana dijelaskan Scott; "Tidak ada kekacauan, demonstrasi, pembakaran, kejahatan sosial yang terorganisir, ataupun kekerasan secara terbuka. Perlawanan yang kami temukan tidak ada kaitannya dengan gerakan-gerakan besar yang manapun dari luar yang bersifat politis, ideologis, atau kader revolusioner, walaupun jelas bahwa gerakan-gerakan yang mirip itu pernah terjadi secara praktis di setiap desa" (Scott 1985).

Fakta yang dipaparkan oleh Scott tersebut, bagi kalangan akademis, hanya menghindarkan petani dari keterbelakangan. Oleh karena itu, petani perlu ada tindakan alternatif untuk diberdayakan. Alternatif ini adalah upaya mengeluarkan petani dari lingkaran ketertindasan struktural. Sikap kritis dalam memetakan kebutuhan kaum tani merupakan salah satu peranan nomor wahid. Para praktisi pembangunan menjadi "orang luar" yang bersifat positif. Mereka menjadi agen perubahan dan bekerja secara langsung hidup merasakan dengan yang diderita oleh kaum tani.

Peran praktisi dan intelektual merupakan keniscayaan karena dipandang sebagai entitas baru dalam dunia perubahan sosial. Adanya peran yang dilakukan oleh praktisi ini, setidaknya, ada banyak torehan prestasi untuk membangun gerakan yang sifatnya terorganisir. Para petani membuat kelompok, kemudian diakomodir oleh praktisi, sehingga petani mampu menyadari betapa pentingnya sebuah gerakan. 
Kegiatan tersebut, bagi para aktivis, merupakan sebuah proses intervensi untuk mengadvokasi kebutuhan riil petani. Advokasi sering menjadi alat sebagai bentuk 'perlawanan' dari pembangunan yang tidak berpihak dan merata. Tentu saja, pembangunan model ini dapat menyebabkan petani berada dalam jurang kemiskinan dan kesenjangan sosial. Dalam satu dasawarsa terakahir, advokasi telah menjadi sebuah paradigma bertindak yang bertujuan untuk membebaskan petani dari bayang-bayang kemiskinan dan ketidakberdayaan.

Pada awalnya, advokasi digunakan untuk membela masyarakat yang bermasalah dengan hukum. Perspektif ini berkembang menjadi istilah litigasi yang digunakan oleh advokat (pengacara). Advokasi litigasi, dalam teori perubahan sosial merupakan sebuah jurang pemisah antara kenyataan dengan konsep advokator. Sebab, litigasi sifatnya kasuistik dan sangat ditentukan oleh perkara yang muncul di pengadilan. Penolakan terhadap advokasi sebagai konsep pembelaan di sidang pengadilan bukan hanya dikhawatirkan akan menyederhanakan persoalan sosial tetapi litigasi menempatkan korban semata-mata sebagai penderita atau korban.

Meski demikian, dalam perspektif perubahan sosial, advokasi digunakan untuk melakukan pembelaan yang sifatnya dilihat dari kacamata korban. Menurut Sharma, advokasi adalah sebuah aksi langsung perubahan kebijakan dalam banyak program di setiap jenis institusi atau lembaga. Oleh sebab itu, advokasi dalam perubahan sosial disebut dengan non litigasi karena advokasi kebijakan dan advokasi hukum (laws advocacy) memiliki perbedaan makna. Advokasi kebijakan, di satu pihak, merupakan istilah re- volusi untuk mempengaruhi keputusan-keputusan sebuah institusi (negara) yang sewenangwenang terhadap rakyatnya. Di pihak lain, advokasi hukum lebih mengarah kepada proses pembelaan bagi yang bermasalah di pengadilan.

Berkaitan dengan hal tersebut, advokasi yang digunakan dalam gerakan sosial kaum tani adalah arah perjuangan sebagai alat revolusi untuk mempengaruhi keputusan atas kesewenangwenangan negara terhadap para petani. Karena itu, advokasi dijadikan sebagai landasan dalam melakukan studi analisis sosial untuk melihat proses penyusunan konsep kebijakan (policy) negara dalam hal pembangunan pertanian. Persoalan kebijakan (policy) dalam bidang pertanian, umumnya, menyoal tentang harga pupuk, kebijakan impor beras, go organic, swasembada pangan, reforma agraria, dan peningkatan kesejahteraan petani.

Lahirnya regulasi kebijakan dalam pembangunan pertanian seringkali melahirkan pro dan kontra. Bagi pihak yang pro, regulasi baru dianggap sebagai angin segar dalam melakukan intervensi. Sementara bagi pihak yang kontra, kondisi ini dilihat sebagai regulasi yang belum tentu menguntungkan petani secara materil. Oleh sebab itu, penafsiran regulasi memiliki makna yang bersifat kontradiktif.

Bagi kalangan aktivis, menafsirkan regulasi, kadang tidak sesuai dengan idealitas persoalan yang dihadapi petani. Tak salah, jika mereka melakukan proses advokasi di luar kesepakatan pemegang kebijakan. Proses ini merupakan pola yang umumnya dilakukan oleh organisasi non pemerintah (ornop) untuk melakukan perubahan terhadap kebijakan pemerintah yang tidak berpihak kepada para petani. 
Pada aspek ini, dapat disimpulkan, gerakan sosial petani cenderung terbuka karena ada aktor luar. Untuk itu, kesadaran untuk melakukan advokasi lebih banyak dilakukan oleh aktivis di bidang pertanian. Dalam kasus ini, peneliti cenderung sepakat dengan analisis yang dikatakan Scott, bahwa "gerakan sosial petani saat ini condong eksploitatif dan demonstratif" (Scott 1985). Oleh karena itu, teori Scott ini, peneliti gunakan sebagai framing analisis yang disesuaikan dengan data-data lapangan.

\section{Arah Baru Gerakan Sosial Petani}

Sub tema ini merupakan jawaban atas pertanyaan apakah betul gerakan sosial petani cenderung menghindari konflik sosial. Dengan titik pijak pada teori Scott, maka hasil penelitian lapangan dapat disajikan sebagai berikut ini.

\section{Konsolidasi Organisasi Petani}

Petani merupakan kelompok sosial yang patut dihargai. Karena itu, sebagai kelompok sosial, petani harus berkembang. Tidak hanya secara kolektif juga secara personal. Kolektvitas kelompok dan personal dapat diwadahi melalui organisasi. Bentuk ini sebagai naungan para petani untuk menyuarakan aspirasi ketika mengalami pergunjingan secara sosial maupun hegemoni kebijakan negara. Basis membangun organisasi petani harus regenerisasi melalui proses kaderisasi. Pun demikian, penting melakukan kegiatan-kegiatan organisasi yang lebih produktif. Basis kegiatan produktif dapat dilakukan melalui pendampingan oleh pihak luar.

Pendampingan adalah bagian tidak terpisah atas kerja advokasi. Kerja kolektif merupakan bentuk advokasi kepada petani atas kasus yang melilit kelompok ini. Kegiatan ini penting untuk membela wong cilik yang terkena dampak kebijakan yang tidak berpihak kepada keberlanjutan (sustainabilitas) kehidupan petani. Eksistensi petani secara berkelanjutan penting dibela. Selain menyuarakan hak asasi, advokasi juga sebagai upaya membangun kohesifitas sosial. Mustahil dapat hasil melawan hegemoni jika tidak dibangun pola dan gerakan petani secara kolektif. Terlebih aral terjal dan berliku menghadang perjuangan petani di Indonesia.

Secara de facto, gerakan petani di Indonesia masih eksis. Namun secara de jure, gerakan petani cenderung tertutup dan tidak tampak di permukaan publik seperti salah satu kasus yang terjadi di Yogyakarta. Apalagi jika jumlah petani tiap hari semakin menyusut. Kondisi ini cukup memprihatinkan. Padahal tangan terampil petani sangat dibutuhkan bagi kehidupan manusia, apa jadinya jika dunia ini tidak ada petani. Kecukupan pangan untuk konsumsi primer manusia akan sangat langka. Bahkan, persoalan yang dapat timbul akibat tidak ada ketersediaan pangan adalah konflik. Begitu mengerikan apabila kehidupan manusia kembali ke zaman purba. Saling sikut, kanibalisasi, atau menjadi pemangsa buas atas sesama manusia. Kondisi ini menjadi masalah serius di tengah modernitas.

Modernisasi merubah pola hidup petani. Hal ini sebagai dampak globalisasi yang menyebabkan dunia menjadi komoditas industri. Perubahan dunia dari cara pandang tradisional menjadi modern membawa arah baru. Era modern cenderung mengabaikan etika. Masyarakat individualistik adalah racun bagi keberlangsungan hidup petani (Ben 1992). Seolah hidup petani dihiasi 
nilai dominan dari 'kepura-puraan' dunia modern (Marcuse 1964).

Berserikat, berkumpul, berorganisasi, dan bergerak bagi petani hanya sebatas ruang aktualisasi diri namun kurang bermakna. Eksploitasi dan hegemoni sebagai pengaruh langsung ideologi kapitalisme mengakibatkan stagnasi perlawanan petani. Perlawanan ini seolah tidak ada makna signifikan bagi perubahan hidup petani. Bahkan kebutuhan prinsip hidup petani pun tidak terpenuhi.

Realitas kehidupan petani yang jauh dari kemapanan menjadi agenda penting bagi para aktivis sosial. Agenda mengubah hidup petani lebih bermartabat adalah masalah utama para aktivis di Yogyakarta. Melalui wadah organisasi, petani mampu unjuk gigi untuk berserikat. Menyuarakan ekspresi diri melalui ragam aktivis perlawanan. Aktivitas ini dilakukan melalui proses kaderisasi. Organisasi yang menjadi wadah petani ini dinamai dengan Serikat Petani Indonesia (SPI). Kegiatan umum yang dilakukan SPI adalah koordinasi dari tingkat pusat hingga daerah. Koordinasi ini adalah upaya menyatukan persepsi untuk menanggapi persoalan agraria yang selama ini masih menjadi persoalan.

"Komunikasi lintas sektoral organisasi sejauh ini masih kami lakukan. Komunikasi model ini sebagai sarana untuk membicarakan isu lokal yang menghimpit kehidupan para petani. Perbincangan lokalitas masalah petani kerap menghasilkan perbincangan dialeketis. Masalah utama yang diangkat pada isu lokal di Yogyakarta adalah eksploitasi tanah" (Abu Sabiqis, wawancara, Februari 2019).

Internal organisasi melakukan konsolidasi secara inten. Cara ini merupakan langkah untuk memperkuat organisasi dalam menghadapi berbagai macam konflik agraria. Konsolidasi ini biasa dilakukan oleh para aktivis petani sekali dalam satu bulan. Memunculkan ide, framing isu, dan menentukan langkah aksi untuk memperjuangkan nasib para petani adalah kegiatan inti dalam setiap pertemuan rutin. Kelompok aktivis petani yang memperbincangkan isu agraria merupakan bentuk perlawanan atas konstalasi politik yang tidak menentu (Wahyudi 2005).

"Setiap bulan kami melakukan rapat untuk memperbincangkan persoalan yang dihadapi petani dengan isu-isu kekinian. Intensitas rapat dan memetakan masalah petani penting kami lakukan. Selain itu, Kami pun diskusi persoalan isu-isu petani lokal khususnya masalah konflik dan kedaulatan pangan" (Tri, wawancara, Februari 2019).

Intensitas pertemuan para petani cukup efektif untuk membicarakan nasib petani yang tidak menentu. Perjuangan yang disuarakan adalah isu kedaulatan pangan. Selain itu, isu agraria juga menjadi fokus organisasi petani. Walaupun isu agraria tidak menjadi agenda utama.

Eksistensi organisasi dapat diketahui dengan semakin kuat forum curahan pendapat, ide, persamaan pengertian, dan persatuan kelompok (Hasibuan 2002). Melalui proses ini serikat petani di Yogyakarta mampu menunjukan eksistensi organisasi. Selain itu juga mampu bergabung dengan forum-forum LSM di Yogyakarta. Terutama kampus yang memiliki pusat studi pertanian, seperti UGM. Hasil konsolidasi dan mobilisasi petani, berbagai aksi dan kegiatan mampu dilakukan. Kegiatan demontrasi pun bergema; deklarasi memperingati Hari Tani Nasional, deklarasi kedaulatan pangan, terlibat dalam ber- 
bagai program desa, kerjasama dengan lembagalembaga riset, dan lain-lain.

Konsolidasi dan mobilisasi di tubuh organisasi, para aktivis petani pun melakukan pendampingan pemahaman produk hukum UU No. 19 Tahun 2013 tentang perlindungan dan pemberdayaan petani yang berbarengan langsung dengan hari tani nasional. Berbagai contoh hasil dari konsolidasi dan mobilisasi massa petani, sejauh ini gerakan Serikat Petani DIY fokus pada persoalan kedaulatan pangan.

Selain pendampingan petani, aktivis sosial memberikan penyuluhan pemahaman tentang perlindungan dan pemberdayaan. Kegiatan ini merupakan bentuk advokasi untuk melindungi petani dari ketidakberdayaan. Perjuangan nasib petani harus terus dilakukan. Tidak ada kata "puas". Itu yang selalu diucap oleh para aktivis. Mobilisasi dan konsolidasi adalah kunci untuk memperkuatgerakan sosial.

\section{Menyuarakan Kembali Hak-Hak Petani}

Revolusi hijau adalah tonggak perubahan mekanisme pertanian Indonesia. Negara hadir sebagai instrumen penting untuk membangkitkan produksi pertanian secara masal. Gerakan ini sempat menjadi pendongkrak ekonomi nasional. Bahkan, Indonesia di era Orde Baru menjadi macan Asia-sebagai negara eksportir beras terbesar di Asia. Surplus hasil produksi pertanian menjadikan bangsa ini sebagai negara super power ekonomi. Negara-negara Asean menjadi ladang ekspor beras (Kuntowijoyo 1992).

Namun torehan prestasi agenda revolusi hijau tidak lagi sesuai harapan subsistensi petani. Agenda pembangunan di sektor pertanian seolah hanya catatan klasik yang tersimpan di museum pertanian. Nasib petani justru terperosok ke dalam lubang kesengsaraan. Tidak banyak petani yang mampu meningkatkan produktifitas ekonomi apalagi harus sejahtera. Petani harus berhadapan langsung dengan kasus agraria. Banyak petani di Indonesia berhadapan dengan konflik akibat aturan negara yang kurang memihak mereka. Alih-alih berlindung kepada negara, petani seakan tercerabut dari akar kehidupanbercocok tanam-karena lahan pertanian menjadi barang yang sangat mahal.

Kondisi ini menjadi masalah serius petani. Subsistensi hidup petani untuk meraih kesejahteraan terus menurun bahkan masuk di area garis kemiskinan. Tidak hanya selesai pada masalah hidup yang kurang menentu. Kondisi global menyebabkan petani harus berjuang ekstra menghadapi pasar industrialisasi. Industri pertanian menuntun petani kepada kerugian dan ketergantungan. Walaupun petani mendapat kemudahan namun harus membayar kerugian (opportunity cost) yang begitu besar, yaitu ketergantungan teknologi dan kerugian ekologi (Susetiawan 2011).

Petani Indonesia mengalami hidup paceklik. Negara ini hadir membela petani hanya sebatas tambal sulam kebijakan. Pemerintah hanya mendorong aspek peralatan dan instrumen industri pertanian. Namun tidak menyentuh akar masalah yang dihadapi. Terlebih di Yogyakarta, petani terlilit oleh aturan Sultan Ground. Bahkan tidak sedikit petani di Yogyakarta harus berhadapan dengan sistem kepemilikan modal asing. Petani penggarap hanya mendapat serpihan kecil dari keuntungan besar (Geertz 1976). ${ }^{1}$ Kondisi ini

\footnotetext{
1Dalam studi yang dilakukan oleh Clifford Geertz, proses perubahan ekologi di Jawa, dalam hal ini fokus pada
} 
berdampak pada penggunaan lahan pertanian yang beralih fungsi menjadi lahan industri dan bisnis.

Data luas penggunaan lahan setiap tahun mengalami penurunan. Jumlah luas tanah 318.580 Ha dengan mengalami penurunan tiap tahun sekitar 0,2 persen. Data menunjukan tiap tahun kehilangan tanah 637 Ha. Tanah petani di rampas oleh pengusaha dan penguasa. Ironisnya, pembelaan negara terhadap nasib petani masih setengah hati.

Persoalan nasib petani menghadirkan tiga spekulasi, antara lain apa konstruksi negara terhadap kondisi tanah dan pangan; apa yang terjadi dibalik konstruksi negara tentang kemakmuran; pembelaan semacam apa yang dilakukan oleh negara kaum industrialisasi (Susetiawan 2011). Dengan begitu, mempertimbangkan nasib petani, gerakan sosial merupakan jalan pintas untuk memperbaiki nasib dan keberlanjutan hidup. Isu reforma agraria adalah perjuangan nomor satu bagi Serikat Petani Indonesia (SPI). Melalui gerakan sosial, para aktivis terus melakukan advokasi bertumpu pada UU Pokok Agraria 1960. UU PA masih menjadi alat petani memperjuangan nasib tanah yang banyak dirampas (Saragih 2011). "Lahan pertanian semakin sempit namun nasib kami tidak

tanah di Yogyakarta, perubahan tekanan penduduk yang tinggi dan lahan atas tanah semakin menyempitnya involusi dan inovasi pertanian melahirkan paradoks pembangunan, sehingga menyebabkan satu dimenasi masa di mana kelas sosial baru bermunculan dengan rasa punya hak memiliki tanah yang mereka tinggali dan pengaruh budaya transaksi kapitalistik, maka lambat laun tanah di Yogyakarta mulai di juali terhadap pemilik modal. jelas apakah masih bisa memiliki tanah". (Sumantoro, wawancara, Februari 2019).

Ekspresi batin petani memang menjadi sebuah kewajaran. Di tengah himpitan pembangunan dan proyek yang terus merajalela. Yogyakarta, sebagai kawasan cagar budaya sedikit banyak sudah tergerus oleh pembangunan hotel, mall, perumahan, dan bandara. Pembangunan ini sudah menjadi ancaman bagi petani. Kehidupan berkelanjutan tampak terancam. Sumber penghidupan keluarga petani semakin tercerabut.

Nasib petani semakin tidak menentu. Untuk itu, eksistensi petani penting disuarakan. Mewadahi petani agar bisa berdaulat dan melanjutkan kehidupan tidak salah jika ada wadah pemersatu. Wadah ini adalah organisasi berupa serikat petani. Melalui organisasi, nasib, renungan, bahkan perubahan kebijakan yang pro kepada petani dapat diwujudkan. Suara ini harus lebih progresif. Tidak kendor bahkan menjadi instrumen perubahan secara radikal. Bahasa lain dapat disebut dengan tindakan aplikatif. Sikap terbuka dan ekspresif adalah kunci memperjuangkan nasib petani di masa mendatang (Hotman 1996; Sulistyaningsih 2013).

"Kami melakukan audiensi kepada pemerintah untuk menyuarakan semua masalah yang dihadapi petani. Pertama, kemarin kami meyuarakan tentang pola tanam yang serempak. Kedua, pupuk yang tidak merata. Ketiga, tidak adanya konsistensi dari pemerintah tentang sosialisasi dan pendampingan terhadap masyarakat" (Sumantoro, wawancara, Februari 2019).

Indonesia, sebagai negara agraris, terkesan kurang berpihak kepada petani. Bahkan nasib petani dan produksi pertanian masih jalan di tem- 


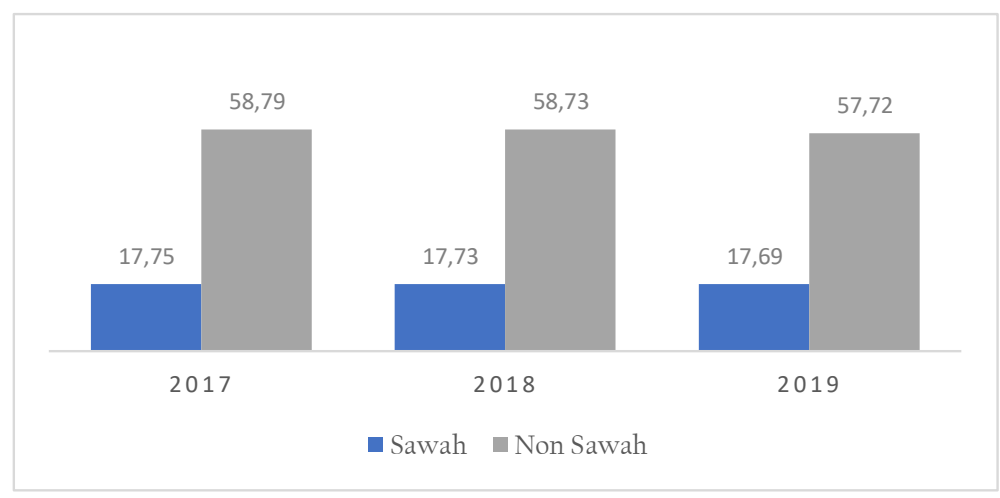

Gambar 1.

Luas Penggunaan Lahan di Propinsi DIY 2017-2019.

Sumber: Diolah dari BPS DIY, 2019.

Tabel 2. Luas Penggunaan Tanah DIY 2017-2019

\begin{tabular}{cccc}
\hline Tahun & $\begin{array}{c}\text { Sawah } \\
\text { (ha) }\end{array}$ & $\begin{array}{c}\text { Non Sawah } \\
\text { (ha) }\end{array}$ & $\begin{array}{c}\text { Total } \\
\text { (ha) }\end{array}$ \\
\hline 2017 & 55.650 & 187.288 & 242.938 \\
2018 & 55.425 & 186.821 & 242.246 \\
2019 & 55.292 & 185.821 & 241.113 \\
\hline
\end{tabular}

Sumber: yogyakarta.bps.go.id, BPS DIY, 2019.

pat. Banyak petani yang hidup di garis kemiskinan. Kesenjangan sosial adalah masalah yang perlu diselesaikan. Negara harus hadir membela para petani. Terutama petani yang memiliki kualitas pendidikan rendah dan identik hidup dipedesaan. Namun kebijakan negara untuk melindungi petani terkesan kasuistik-berpihak setengah hati (Maksum 2004).2

Petani seolah tidak berdaya. Negara hadir tidak memberi solusi. Bahkan petani di Yogya-

\footnotetext{
${ }^{2}$ Dalam pandangan Maksum, kondisi yang dikatakan setengah hati, adalah corak pemikiran teknokrat yang masih memiliki pemikiran profit oriented sehingga segala kebijakan yang dikeluarkan mengenai rancangan strategis pembangunan di bidang pertanian sangat korporatis dan neoliberalistis. Fenomena ini jelas merupakan sebuah kesesatan pola pikir.
}

karta harus berhadapan dengan para penyuluh lapangan. Ada banyak produk undang-undang yang dihasilkan namun kurang berdampak sistemik kepada perubahan nasib petani. UU dan penyuluh pertanian tidak memberikan perubahan yang signifikan. Ada yang hanya menjalankan fungsi negara-karena sebagai PNSnamun masalah utama petani diabaikan.

Negara belum mampu mengakomodir dengan baik kebutuhan riil petani. Paling menonjol kasus pertanian adalah masalah kontrol produksi hasil panen. Banyak ditemukan korporasi yang tidak berpikir panjang. Di masa panen petani harusnya mendapat keuntungan. Namun yang terjadi adalah tidak berdampak baik bagi kehidupan petani. Justru cenderung lebih sengsara 
akibat permainan kartel elit negeri ini ${ }^{3}$ Jones 2010).

Sistem oligarki dan demokrasi liberal Indonesia menuntut aparatur negara harus tunduk kepada korporasi. Di masa panen petani harusnya mendapat keuntungan. Namun kondisi ini tidak pernah terjadi. Bahkan, penulis menemukan kasus di daerah Lereng Merapi yang secara umum petani menanam cabai. Di waktu panen, harga cabai dari petani tidak sesuai dengan modal saat menanam. Petani protes dengan turun ke jalanan. Cabai hasil panen ditebar di jalanan. Para petani menganggap tidak ada untung menjual hasil panen jika harga dipasaran tidak seimbang. Lebih baik melakukan protes di jalanan menabur hasil panen Cabai.

Kasus permainan harga di pasaran jelas masuk ke dalam ranah oligarki dan politik kartel. Pasca reformasi, Indonesia masih diterpa berbagai masalah sistem bernegara. Tantangan nyata yang dihadapi negeri ini adalah politik transaksional dan oligarki (Winters 2013). Kontrol produksi pertanian masih tetap tersentral di pusat. Miopi impor menjadi kendala para petani. Tak salah jika petani menjadi korban sistem negara liberal. Jangan berharap banyak bagi kebangkitan nasional dari aras lokal jika nasib petani tidak diperhatikan.

\footnotetext{
${ }^{3}$ Menurut kaum Marxis, ketika sistem feodalisme berlangsung, inovasi teknologi mulai mengubah sifat-sifat dasar produksi, dari pertanian intensif dengan menggunakan tenaga kerja manusia menjadi pertanian dengan menggunakan mesin, dan akhirnya menjadi produksi industri. Ketika gelombang perubahan pertanian dan industri terjadi, maka kelas kapitalis yang baru pun muncul sebagai pemilik sarana produksi yang baru tersebut-ini menjadi modal
}

Negara vis a vis petani menjadi masalah baru. Menyikapi persoalan ini petani harus bersuara. Jangan sampai negara berpihak kepada kaum pemodal besar. Regulasi haris membela kepentingan petani untuk meningkatkan kesejahteraan. Keluh kesah petani masih penulis temukan di lapangan.

"Pihak asing menjadi masalah. Ketika kami melakukan advokasi, pemrintah bermain mata dengan pihak pemilik modal, seperti adanya undang-undang air yang baru disahkan pada tahun 2010, melarang petani membuat budidaya. Kondisi ini banyak yang bergelap mata seperti sogokmenyogok" (Sukijan, wawancara, Maret 2019).

Ratapan nasib petani harus segera dihentikan. Perjuangan hak asasi petani menjadi isu yang didorong oleh para aktivis dan LSM di Yogyakarta. Tugas SPI menyuarakan hak asasi petani sebagai basis perjuangan pembaruan agraria dan kedaulatan pangan merupakan satu kesatuan yang tidak bisa dipisahkan. Karena itu, SPI terus mengawal kasus-kasus agraria dan hak-hak petani di DIY.

\section{Gerakan Sosial Berbasis Pemberdayaan}

Petani melakukan gerakan sosial di antara kepentingan pribadi dan kolektifitas pemerintah. Peran pemerintah sebagai keterwakilan negara sudah berubah menjadi 'sekongkol' dengan investor. Pemilik modal besar cenderung mengabaikan kepentingan petani. Satu sisi, negara hadir membuka klan investasi. Di sisi lain, negara kurang responsif terhadap persoalan nasib petani. Pemerintah cenderung lupa bahkan lalai atas kewajiban melindungi petani. Bahkan, pembangunan menjadi keuntungan swasta. 
Untuk menyuarakan nasib petani, peran organisasi sudah harus melakukan gerakan advokasi. Advokasi kebijakan agraria dan kedaulatan pangan harus menjadi alternatif pembangunan. Pelibatan aktif masyarakat perlu di dorong sebagai kontrol terhadap negara. Selain itu, partisipasi masyarakat bisa berhasil jika masyarakat bersatu (Midgley 1995).

Organisasi petani berpotensi melakukan perubahan secara radikal. Pondasi utama melakukan penyadaran kepada petani. Kekuatan dan loyalitas adalah kunci perubahan. Untuk itu, perlu merumuskan (social planning) strategi advokasi. Hal ini beranggapan bahwa negara bukanlah musuh.

Gerakan advokasi kebijakan harus beriringan dengan kepentingan petani. Posisi tepat adalah menjadi oposisi negara. Dengan mempertimbangkan progres regulasi yang disusun. Agar tidak melenceng dari cita-cita ideal. Langkah gerakan harus terbuka. Tidak bisa lagi terselubung dan diam-diam.

Para aktivis petani harus memiliki kredibiltas. Harus mampu meletakan pondasi dasar perjuangan untuk berpihak kepada petani secara utuh. Ketika negara berseberangan dengan kepentingan petani harus dikritik melalui wacana konstruktif dan progresif. Jika wacana ini terimplementasi kepada tindakan akan epik.

Bentuk kongkret wacana itu adalah pendampingan kelompok petani rentan. Kegiatan pemberdayaan adalah bentuk nyata. Kegiatan ini merupakan proses pendampingan petani dan secara spesifik memberdayakan kolompok dengan efisien sesuai kebutuhan. Pemberdayaan bagi petani adalah proses yang sangat penting karena tanpa adanya proses seperti macan tidak bertaring (Debal 1995). ${ }^{4}$ Selain itu, rencana aksi merupakan kegiatan utama yang dilakukan oleh SPI. Sebagai perlawanan kepada hegemoni dan sistem yang kapitalistik. Konsep ini merupakan pengembangan yang menuntut petani lebih kreatif dan inovatif. Sistem dibangun dengan menyatukan persepsi secara kolektif.

"Salah satunya nanti kita harus berdaya. Kita sebagai petani harus melawan dengan konsep pemberdayaan. Petani dituntut kreatif maka perlawanannya secara halus. Kalau kita melakukan perlawanan secara prontal justru malah melawan militer. Ketika petani di ajak berpikir menyoal regulasi, seperti perundang-undangan dan sebagainya, kegiatan ini akan nyambung. Jadi sebenarnya teman-teman aktivis mahasiswa, aktivis LSM, menjadi penyambung lidah rakyat" (Sumantoro, wawancara, Maret 2019).

Persoalan pertanian memang kompleks. Apalagi sistem sosial yang lebih menguntungkan para pemodal. Menanggapi kondisi ini, tidak bisa melakukan perubahan secara frontal. Jika pun harus melawan tidak bisa berhadapan langsung dengan instrumen negara-misal TNI. Namun perlu strategi yang sesuai dengan kebutuhan. Kebutuhan nyata petani adalah meningkatkan kemampuan individu untuk menghadapi era

\footnotetext{
${ }^{4}$ Pemberdayaan bagi petani (peasent of empowerment) identik dengan gerakan-gerakan sosial. Menurut Debal, pemberdayaan bagi petani adalah sebuah proses perubahan mendasar yang harus dilakukan karena pada dasarnya memiliki ketidakseimbagan antara pendistribusian dan relasi dari otoritas kekuasaan. Hal ini merupakan sebuah proses pendayagunaan kekuatan petani untuk pendistribusian dari bawah yang lebih merata. Dengan begitu, pemberdayaan petani sebagai proses yang memiliki tujuan secara alamiah dari petani dengan corak intervensi sosial.
} 
modern. Berdamai adalah modal bergerak ke arah perubahan sosial. Kelas sosial baru harus tercipta. Petani perlu diberdayakan. Modal sosial dan cost-benefit ialah kunci perubahan hidup petani. Dengan begitu, muara akhir dari gerakan sosial menciptakan petani yang menguasai skill di bidang pertanian secara aplikatif. Berdaya adalah modal sosial yang tidak dapat ditawar jika petani ingin maju dan sejahtera.

\section{Kesimpulan}

Bentuk gerakan sosial petani sudah kompromistik. Dengan adanya konsolidasi organisasi, menyuarakan hak-hak petani menjadi bagian dari bentuk perlawanan. Tidak mungkin dapat terwujud sebuah perlawanan secara masif jika organisasi petani tidak dibentuk. Untuk itu, konsolidasi organisasi petani menjadi instrumen penting untuk melakukan perjuangan membela kepentingan secara kolektif.

Bentuk konsolidasi organisasi petani adalah cerminan dari perlawanan sosial yang terbuka. Teori Scott tercermin dalam perjalanan panjang gerakan sosial petani di Yogyakarta. Gerakan sosial yang dilakukan menjadi mekanisme yang ekspresif dan terbuka. Demontrasi menyuarakan kepentingan petani adalah bukti kesadaran kolektif petani untuk menentukan nasib hidup mereka. Tentu saja konteks ini terlihat dalam gerakan sosial yang menyuarakan hak-hak petani.

Tulisan ini mencerminkan refleksi teoritis pemikiran Scott. Penulis pun berpendapat, petani di era modern sudah maju dan terbangun kelompok sosial baru secara kolektif. Sebagai sosiolog, Scott memberikan perspektif baru dalam menarasikan gerakan perlawanan dari para petani. Khususnya petani yang cenderung mengalami penindasan akibat sistem sosial. Untuk itu, penulis memberi kesimpulan sederhana. Artikel ini mampu memberi perspektif baru atas gerakan sosial yang dilakukan di Yogyakarta. Memang masih menyimpan persoalan yang belum terungkap. Namun pada aspek perjuangan petani, tulisan ini menyodorkan tawaran baru bagi para peneliti selanjutnya, apa yang salah dalam pola perjuangan sosial petani di Indonesia. Di tengah himpitan masalah kesetaraan dan keadilan sosial yang belum terwujud. Pekerjaan rumah yang perlu diperluas adalah mekanisme yang tepat untuk memberdayakan petani.[]

\section{Daftar Pustaka}

Adriani, Dessy. 2015. “Rasionalitas Sosial-Ekonomi dalam Penyelesaian Pengangguran Terselubung Petani Tadah Hujan." Masyarakat: Jurnal Sosiologi 20(80):43-58.

Ben, Agger. 1992. The Discourse of Domination from the Frankfurt School to Postmodernism. Illinois: Northwestern University Press.

Debal, Singha K. Roy. 1995. "Peasant Movements and Empowerment of Rural Women." Economic and Political Weekly 30(37): 2306-11.

Geertz, Clifford. 1976. Involusi Pertanian: Proses Perubahan Ekologi di Indonesia. Jakarta: Bhatara Karya Aksara.

Hasibuan, Malayau. 2002. Manajemen Pasar: Pengertian dan Masalah. Jakarta: Gunung Agung.

Hotman, M. Siahaan. 1996. "Pembangkangan Terselubung Petani dalam Program Tebu Rakyat Intensifikasi (TRI) sebagai Upaya 
Mempertahankan Subsistensi." Disertasi. Universitas Airlangga, Surabaya.

Husain, Fadly, Gunawan Gunawan, Thriwaty Arsal, Asma Luthfi, dan Hartati Sulistyo Rini. 2018. "Jaringan dan Sistem Sosial dalam Distribusi Komoditas Pertanian Lahan Kering." JSW Ournal Sosiologi Walisongo) 2(2):123-36.

Izudin, Ahmad. 2017. Gerakan Sosial Petani: Strategi, Pola, dan Tantangan di Tengah Modernitas. Yogyakarta: Samudra Biru.

Jones, Pip. 2010. Pengantar Teori-Teori Sosial: Dari Teori Fungsionalisme hingga Post-Modernisme. Jakarta: Yayasan Obor Indonesia.

Kuntowijoyo. 1992. Esei-Esei Sejarah Radikalisasi Petani. 2 ed. Yogyakarta: Bentang.

Maksum, Mochammad Machfoedz. 2004. "Mengkritisi Berbagai Kendala Struktural Sektor Pertanian." dalam Pembangunan Pertanian 2003-2004 sebagai Landasan Kebijakan Pembangunan Pertanian. Yogyakarta: Fakultas Pertanian UGM.

Marcuse, Herbert. 1964. One-Dimension Man. Boston: Beacon.

Midgley, James. 1995. Social Development: The Developmental Perspective in Social Welfare. London: Sage Publications.

Miles dan Huberman. 1994. Qualitative Data Analisys. USA: Sage Publication.

Moleong, Lexy. J. 2010. Metodologi Penelitian Kualitatif. Bandung: Remaja Rosdakarya.

Rahmat, A. dan A. Izudin. 2018. "Impact Evaluation of Community Empowerment Programs with the Farmer Managed Extension Model." European Research Studies Journal XXI(2):225-35.

Rahmawati, Desi. 2003. “Gerakan Petani dalam Konteks Masyarakat Sipil Indonesia: Studi
Kasus Organisasi Petani Serikat Tani Merdeka (SeTAM)." Jurnal Ilmu Sosial dan Ilmu Politik 6(3):329-58.

Saragih, Hendry. 2011. "Kedaulatan Pangan di Tengah Korporatisasi Pangan." dalam Ekonomi Politik Pangan Kembali ke Basis: Dari Ketergantungan ke Kedaulatan. Jakarta: Yayasan Bina Desa.

Scott, James. 1985. Weapons of the Weeks: Everyday Form of Peasant Resistance. Yale: Yale University Press.

Sudibyo, Agus. 1999. "Wacana Penjarahan dan Kekerasan Simbolik terhadap Petani." Jurnal Ilmu Sosial dan Ilmu Politik 2(3):7189.

Suharko, Suharko. 2006. "Gerakan Sosial Baru di Indonesia: Repertoar Gerakan Petani." Jurnal Ilmu Sosial dan Ilmu Politik 10(1):134.

Sulistyaningsih. 2013. Perlawanan Petani Hutan Studi Atas Resistensi Berbasis Pengetahuan Lokal. Yogyakarta: Kreasi Wacana.

Susetiawan. 2011. "Para Petani yang Tersisa dan Nasionalisme." dalam Ekonomi Politik Pangan Kembali ke Basis: Dari Ketergantungan ke Kedaulatan. Jakarta: Yayasan Bina Desa.

Wahyudi. 2005. Formasi dan Struktur Gerakan Sosial Petani Studi Kasus Reklaiming atau Penjarahan Atas Tanah PTPN XII (Persero) Kalibakar Malang Selatan. Malang: UMM Press.

Winters, Jeffrey. 2013. Oligarchy and Democracy in Indonesia. New York: Southeast Asia Program at Cornell University. 